\title{
FAKTOR-FAKTOR PENYEBAB PERGESERAN TENAGA KERJA SEKTOR PERTANIAN KE SEKTOR NON PERTANIAN DI KECAMATAN KALAWAT, KABUPATEN MINAHASA UTARA
}

\author{
Claudio Stylone Pesik \\ Gene H.M. Kapantow \\ Theodora M. Katiandagho
}

\begin{abstract}
This study aims to determine what factors are causing the shift of labor from agriculture to non-agricultural sectors in the District of Kalawat, North Minahasa Regency. Factors that cause the shift of labor can be divided into two categories namely, the driving factors of the agricultural sector and the pull factors of the non-agricultural sector so that agricultural labor tend to leave work in the agricultural sector and chose to work in the non-agricultural sector. The research was conducted from August to October 2016. The data collection includes primary data and secondary data. Methods of primary data collection were used interview techniques. Methods of sample selection were used Quota sampling method. The number of respondents who were interviewed 30 respondents. The characteristics of the respondents selected were those who used to work in the agricultural sector but have switched jobs to non-agricultural sector. Secondary data were obtained from the District Office of Kalawat, North Minahasa Regency. Data analysis methods are applied in this research using descriptive method. The results showed that the main driving factors that cause labor to leave work in the agricultural sector are income in agriculture is fluctuation and low as well as the availability of agricultural land is shrinking. The main pull factor of the non-agricultural sector is increasingly opening up opportunities and employment in non-agricultural sectors. Other pull factors were earnings in non-agricultural sector and conditions of employment are more promising.
\end{abstract}

Keywords: factors, the shift of labor, agriculture, non-agricultural, North Minahasa Regency

\begin{abstract}
ABSTRAK
Penelitian ini bertujuan untuk mengetahui faktor-faktor apa saja yang menyebabkan pergeseran tenaga kerja dari sektor pertanian ke sektor non pertanian di Kecamatan Kalawat, Kabupaten Minahasa Utara. Faktor-faktor penyebab pergeseran tenaga kerja ini dapat dibagi dalam dua kategori yakni, faktor pendorong dari sektor pertanian dan faktor penarik dari sektor nonpertanian sehingga tenaga kerja pertanian meninggalkan pekerjaan di sektor pertanian dan memilih untuk bekerja di sektor non pertanian. Penelitian ini dilaksanakan sejak Bulan Agustus sampai Bulan Oktober 2016 di Kecamatan Kalawat Kabupaten Minahasa Utara. Pengumpulan data meliputi data primer dan data sekunder. Metode pengumpulan data menggunakan teknik wawancara. Metode pemilihan sampel menggunakan metode Quata Sampling. Jumlah responden yang diwawancara sebanyak 30 responden. Ciri-ciri responden yang dipilih adalah mereka yang dahulunya bekerja di sektor pertanian namun telah beralih pekerjaan ke sektor non-pertanian di Kecamatan Kalawat Kabupaten Minahasa Utara. Data sekunder diperoleh dari Kantor Kecamatan Kalawat, Kabupaten Minahasa Utara. Metode analisis data yang diterapkan dalam penelitian ini menggunakan Metode Deskriptif. Hasil penelitian menunjukan bahwa, faktor pendorong utama yang menyebabkan tenaga kerja meninggalkan pekerjaan di sektor pertanian adalah pendapatan di sektor pertanian yang tidak menentu dan rendah serta ketersediaan lahan pertanian yang semakin berkurang. Faktor penarik utama dari sektor non-pertanian adalah semakin terbukanya peluang dan kesempatan kerja di sektor non- pertanian. Faktor penarik lainnya adalah pendapatan di sektor non-pertanian dan kondisi pekerjaan yang lebih menjanjikan.
\end{abstract}

Kata Kunci: faktor, pergeseran tenaga kerja, sektor pertanian, non pertanian, Kabupaten Minahasa Utara 


\section{PENDAHULUAN}

\section{Latar Belakang}

Pembangunan adalah suatu proses perubahan menuju ke arah kehidupan yang lebih baik dengan meningkatkan taraf hidup dan kesejahteraan seluruh rakyat dari kehidupan sebelumnya. Proses pembangunan dapat diartikan sebagai upaya memenuhi kebutuhan pokok rakyat yang berarti bahwa pembangunan mencakup kebutuhan primer (sandang, pangan, dan papan) serta kebutuhan sekunder (pendidikan, keamanan, dan kesehatan). Pembangunan mengandung arti dalam dirinya unsur perubahan besar, yaitu perubahan struktur ekonomi, perubahan struktur sosial, perubahan fisik wilayah, perubahan struktur ekonomi, perubahan pola konsumsi, perubahan sumber alam dan lingkungan hidup, perubahan teknologi, perubahan sistem nilai dan kebudayaan (Salim dalam Noragawati, 2002). Sektor pertanian yang awalnya merupakan sektor yang diandalkan bagi perkembangan perekonomian bangsa Indonesia, seiring berjalannya waktu dan pengembangan pembangunan juga dampak dari modernisasi, sektor pertanian mengalami penurunan dan perkembangan sektor non pertanian mengalami kemajuan khususnya sektor Industri, dan juga sampai saat ini terus mengalami peningkatan. Pembangunan industri secara luas meliputi industri primer (pertambangan), industri sekunder (konstruksi dan manufaktur), serta industri tersier (transportasi, komunikasi dan sektor jasa lainnya). Semakin sempitnya lahan pertanian di wilayahwilayah Indonesia diakibatkan oleh alih fungsi lahan pertanian menjadi tempat pemukiman yang didasari oleh lajunya pertumbuhan penduduk yang pesat, serta berkembangnya sektor non pertanian mengakibatkan lahan pertanian dijadikan lahan untuk kegiatan-kegiatan sektor non pertanian. Hal ini membuat sektor pertanian tidak bisa lagi menampung tenaga kerja yang banyak mengingat lahan pertanian yang semakin kecil dan didorong oleh perkembangan teknologi modernisasi sehingga tenaga kerja manusia diganti oleh tenaga kerja mesin. Berkurangnya lahan pertanian di suatu wilayah yang didukung oleh pertumbuhan penduduk yang pesat serta masuknya sektor non pertanian di suatu wilayah pertanian akan mengakibatkan pergeseran tenaga kerja atau beralihnya pekerja-pekerja sektor pertanian akan keluar dan mencari pekerjaan di luar sektor pertanian.
Salah satu wilayah di Indonesia yang lahan pertaniannya semakin berkurang yaitu Kecamatan Kalawat Kabupaten Minahasa Utara. Pada tahun 2012/2013 luas lahan panen Kecamatan Kalawat adalah 6.257,67 hektar dan pada tahun 2013/2014 menjadi 3.959,67 hektar, hal ini berarti lahan pertanian di Kecamatan Kalawat Kabupaten Minahasa Utara mengalami penurunan (BPS Minahasa Utara).

Menurut Iqbal dan Sumaryanto dalam Dinaryanti (2014), Lahan pertanian adalah yang paling rentan terhadap alih fungsi adalah sawah. Hal ini disebabkan oleh:

1. Pembangunan sarana dan prasarana pemukiman, kawasan industri, dan sebagainya berlangsung cepat.

2. Kepadatan penduduk di pedesaan yang mempunyai agroekosistem dominannya adalah sawah pada umumnya jauh lebih tinggi dibandingkan agroekosistem lahan kering, sehingga tekanan penduduk atas lahan juga tinggi.

3. Daerah pesawahan banyak yang lokasinya berdekatan dengan daerah perkotaan.

Dapat dilihat dari hal ini, lahan pertanian Kecamatan Kalawat juga termasuk dalam kategori lahan pertanian yang rentan terhadap alih fungsi lahan. Alih fungsi lahan juga didorong oleh laju pertumbuhan penduduk yang cepat yang dapat dilihat dalam Tabel 1. Dalam Tabel 1 dapat dilihat bahwa jumlah penduduk Kecamatan Kalawat mengalami peningkatan jumlah penduduk pada tahun 2014. Dengan bertambahnya jumlah penduduk di Kecamatan Kalawat dan menurunnya lahan pertanian di Kecamatan Kalawat yang didorong oleh pertumbuhan penduduk yang membuat masyarakat mengkonversi lahan mereka untuk dijadikan pemukiman juga dijadikan lahan kegiatan non pertanian memungkinkan tenaga kerja sektor pertanian keluar dari sektor pertanian dan mencari pekerjaan di luar sektor pertanian, karena lahan pertanian semakin kecil dan tidak dapat menampung banyak tenaga kerja. Pertumbuhan penduduk yang cepat juga membuat angkatan kerja juga mengalami peningkatan. Dengan lahan pertanian yang semakin lama semakin menurun membuat angkatan kerja ini tidak akan tertampung disektor pertanian, hal ini membuat para angkatan kerja baralih pekerjaan atau mencari pekerjaan disektor non pertanian.

Dari Tabel 2 dapat dilihat bahwa penduduk yang sudah bekerja di Kecamatan Kalawat Kabupaten 
Minahasa Utara berjumlah 10.139 orang dan yang belum bekerja berjumlah 6.012 orang. Dengan pertumbuhan penduduk yang cepat menghasilkan angkatan kerja yang besar dengan tingkat pengangguran dan penduduk yang belum bekerja atau sedang mencari pekerjaan juga menjadi banyak. Hal ini juga dapat disebabkan oleh alih fungsi lahan pertanian menjadi tempat pemukiman dan dijadikan lahan industri dengan resiko penduduk yang mengkonversi lahan pertanian mereka tidak bisa lagi bekerja di pertanian karena lahan mereka telah dijual dan dijadikan tempat pemukiman atau lahan industri dan mereka akan keluar dan beralih pekerjaan disektor-sektor lain. Di Provinsi Sulawesi Utara khususnya Kabupaten Minahasa Utara merupakan salah satu kabupaten yang pembangunan sektor industrinya sangat cepat dari daerah daerah yang lain. Di daerah ini merupakan salah satu daerah yang sudah banyak kegiatan non pertanian, baik industri perusahaan maupun industri perseorangan, juga menjadi daerah yang sektor jasanya terus meningkat. Kecamatan Kalawat merupakan salah satu Kecamatan di Minahasa Utara yang memiliki banyak Industri dan jasa di wilayahnya

Tabel 1. Jumlah Penduduk Menurut Desa di Kecamatan Kalawat Kab. Minahasa Utara Tahun 2013-2014

\begin{tabular}{lcc}
\hline \multicolumn{1}{c}{ DESA } & \multicolumn{2}{c}{ TAHUN } \\
\cline { 2 - 3 } & 2013 & 2014 \\
\hline Maumbi & 2.629 & 2.771 \\
Watutumou & 4.243 & 4.243 \\
Watutumou II & 2.376 & 2.535 \\
Watutumou III & 2.310 & 2.169 \\
Kalawat & 2.699 & 2.618 \\
Kawangkoan Baru & 2.433 & 2.773 \\
Kolongan Tetempengan & 3.610 & 3.682 \\
Kawangkoan & 1.812 & 1.812 \\
Kolongan & 2.453 & 2.310 \\
Suwaan & 1.852 & 2.095 \\
Kuwil & 943 & 925 \\
Kaleosan & 686 & 686 \\
\hline \multicolumn{1}{c}{ JUMLAH } & 28.046 & 28.619 \\
\hline
\end{tabular}

Sumber: Kalawat Dalam Angka, Katalog BPS.

Tabel 2. Jumlah Penduduk Usia 15-64 Tahun dan Jumlah Penduduk yang Bekerja dan yang Belum Bekerja Menurut Desa Tahun 2014

\begin{tabular}{lccc}
\hline \multicolumn{1}{c}{ DESA } & USIA 15-64 & BEKERJA & BELUM \\
\hline Maumbi & 1.600 & 1.173 & 427 \\
Watutumou & $*$ & $*$ & $*$ \\
Watutumou II & 1.913 & 724 & 1.189 \\
Watutumou III & $*$ & 903 & $*$ \\
Kalawat & 1.678 & 1.635 & 43 \\
Kawangkoan Baru & 1.939 & 899 & 1.040 \\
Kolongan Tetempengan & 2.652 & 553 & 2.119 \\
Kawangkoan & 1.244 & 647 & 597 \\
Kolongan & 1.655 & 1.874 & $*$ \\
Suwaan & 1.420 & 984 & 436 \\
Kuwil & 689 & 528 & 161 \\
Kaleosan & $*$ & 219 & $*$ \\
\hline JUMLAH & 14.790 & 10.139 & 6.012 \\
\hline
\end{tabular}

Sumber: Kalawat Dalam Angka, Katalog BPS. 


\section{Rumusan Masalah}

Berdasarkan latar belakang yang telah diuraikan di atas, maka yang menjadi permasalahan dalam penelitian ini adalah terjadinya pergeseran tenaga kerja dari sektor pertanian ke sektor non pertanian yang di pengaruhi oleh pertumbuhan penduduk yang cepat serta pembangunan ekonomi dan pembangunan infrastrukutur di Kecamatan Kalawat maka peneliti tertarik untuk meneliti tantang faktorfaktor apa saja yang menyebabkan pergeseran tenaga kerja sektor pertanian ke sektor non pertanian.

\section{Tujuan Penelitian}

Sesuai dengan latar belakang dan perumusan masalah, maka tujuan dari penelitian ini adalah untuk mengetahui faktor-faktor yang menyebabkan pergeseran tenaga kerja sektor pertanian ke sektor non pertanian di Kecamatan Kalawat Kabupaten Minahasa Utara.

\section{Manfaat Penelitian} kegunaan:

Penelitian ini diharapkan memiliki

1. Digunakan sebagai wadah belajar tentang pergeseran tenaga kerja serta dampak dari sektor industri yang muncul di daerah pedesaan.

2. Memberikan wawasan serta bahan pertimbangan atau dikembangkan lebih lanjut.

\section{METODE PENELITIAN}

\section{Waktu dan Tempat Penelitian}

Penelitian ini dilakukan selama tiga bulan yaitu bulan Agustus 2016 sampai bulan Oktober 2016. Lokasi yang akan dijadikan tempat penelitian adalah Kecamatan Kalawat

Kabupaten Minahasa Utara. Pemilihan lokasi ini dipilih dengan pertimbangan Kecamatan Kalawat merupakan salah satu kawasan yang pertumbuhan industri dan perumahannya tergolong cepat.

\section{Metode Pengumpulan Data}

Jenis pengumpulan data dalam penelitian ini meliputi data primer dan data sekunder. Data primer dikumpulkan dengan menggunakan metode wawancara dengan mengajukan pertanyaan untuk dijawab. Pengambilan sampel atau responden menggunakan metode Quota Sampling. Quota Sampling adalah teknik untuk menentukan sampel dari populasi yang mempunyai ciri-ciri tertentu sampai jumlah kuota yang diinginkan. Penentuan sampel didasarkan terhadap masyarakat yang telah beralih pekerjaan dari sektor pertanian ke non sektor pertanian dalam jangka waktu 5 tahun terakhir. Kuota sampel responden yang akan diwawacara sebanyak 30 responden. Data primer juga meliputi data karakteristik responden dan alasan responden meninggalkan sektor pertanian. Data sekunder dilkumpulkan melalui metode documenter (penelusuran dokumentasi), sumber datanya berupa catatan atau dokumen yang terdapat di kantor Kecamatan dan instansi terkait.

\section{Konsep Pengukuran Variabel}

Faktor-faktor penyebab pergeseran tenaga kerja dari sektor pertanian dibagi dalam dua faktor yaitu faktor pendorong dari sektor pertanian sehingga tenaga kerja meninggalkan sektor pertanian dan faktor penarik dari sektor non pertanian sehingga tenaga kerja yang keluar dari sektor pertanian memilih untuk bekerja di sektor non pertanian.

1. Faktor-faktor pendorong dari sektor pertanian sehingga tenaga kerja keluar dari sektor pertanian antara lain:

1) Upah di sektor pertanian yang tidak menentu/rendah

2) Lahan yang semakin menyempit/lahan sudah tidak ada

3) Pandangan rendah terhadap pekerjaan di pertanian.

4) Jenuh/bosan bekerja di pertanian

2. Faktor penarik dari sektor non pertanian sehingga tenaga kerja memilih untuk bekerja di sektor non pertanian antara lain:

1) Peluang atau kesempatan kerja terbuka.

2) Pendapatan tetap dan cepat juga lebih menjanjikan.

3) Kondisi pekerjaan yang lebih menjanjikan. 


\section{Analisis Data}

Data primer yang diperoleh akan diolah secara deskriptif. Faktor-faktor penyebab pergeseran tenaga kerja sektor pertanian yang dibagi menjadi dua faktor yaitu, faktor pendorong dari sektor pertanian sehingga tenaga kerja sektor pertanian keluar dari sektor pertanian dan faktor penarik dari sektor non pertanian sehingga tenaga kerja memilih untuk bekerja di sektor non pertanian akan disajikan dengan Tabelaris kemudian diuraikan secara deskriptif.

\section{HASIL DAN PEMBAHASAN}

\section{Gambaran Umum Lokasi Penelitian}

\section{Keadaan Fisik Wilayah}

Kecamatan Kalawat sebagai lokasi penelitian ini adalah salah satu kecamatan di Kabupaten Minahasa Utara Propinsi Sulawesi Utara yang telah mengalami pemekaran wilayah yang disebabkan oleh pertumbuhan jumlah penduduk yang banyak. Akibat dari pertumbuhan jumlah penduduk inilah yang membuat lahan-lahan pertanian di Kecamatan Kalawat di alihfungsikan untuk dijadikan tempat pemukiman. Tidak hanya disebabkan oleh pertumbuhan penduduk alihfungsi lahan pertanian juga disebabkan oleh pembangunan ekonomi dan pembangunan infrastrukutur seperti pembangunan jalan tol dan juga dijadikan lahan pekuburan. Masuknya sektor non pertanian di Kecamatan Kalawat juga mengakibatkan lahan pertanian dijadikan tempat untuk kegiatan sektor non pertanian.

Kecamatan Kalawat berada di ketinggian \pm 500 meter dari atas permukaan laut. Kecamatan Kalawat ini terdiri dari 12 desa dengan luas 44,21 km2 yaitu Desa Maumbi, Watutumou, Watutumou II, Watutumou III, Kalawat, Kawangkoan, Kawangkoan Baru, Kolongan, Kolongan Tempengan, Suwaan, Kuwil dan Desa Kaleosan dngan batas administrasi sebagai berikut:

1. Sebelah Utara dengan Kecamatan Dimembe dan Kecamatan Talawaan

2. Sebelah Timur dengan Kecamatan Airmadidi

3. Sebelah Selatan dengan Kecamatan Airmadidi

4. Sebelah Barat dengan Kota Manado dan Kecamatan Minahasa
Penggunaan lahan di Kecamatan Kalawat terbagi atas dua penggunaan yaitu digunakan sebagai lahan pertanian dan digunakan sebagai lahan non pertanian. Lahan pertanian dibagi atas dua keperluan yaitu digunakan sebagai sawah sebesar 143,36 km2 dan non sawah sebesar $626,87 \mathrm{~km} 2$ dan untuk penggunaanya di non pertanian sebesar 421,72 km2 ( Katalog Kalawat Dalam Angka, 2016).

\section{Penduduk}

Jumlah Penduduk Kecamatan Kalawat pada saat penelitian yang diambil dari dokumen di kantor Badan Pusat Statistik dalam "Katalog Kecamatan Kalawat Angka 2016" berjumlah 28.619 jiwa pada tahun 2015 dengan jumlah keluarga sebanyak 8.149 keluarga. Jumlah populasi penduduk tersebut terdiri dari 14.295 orang laki-laki sedangkan jumlah penduduk perempuan sebanyak 14.324 orang. Penduduk golongan usia produktif yaitu pada rentang usia 15-64 tahun berjumlah 14.790 orang dan penduduk yang berusia non produktif pada tentang usia 0-14 tahun berjumlah 4.72 orang, sedangkan pada golongan usia non produktif pada umur 65 tahun keatas sebanyak 2.005 orang. Potensi golongan penduduk usia produktif di Kecamatan Kalawat ini relatif lebih besar dibandingkan dengan usia non produktif.

\section{Karakteristik Responden}

\section{Umur}

Tingkat umur responden yang telah beralih pekerjaan dari sektor pertanian ke sektor non pertanian bervariasi, mulai dari responden yang berumur 20-an sampai responden yang berumur 60 -an. Hal ini dikarenakan tidak ada ketentuan mengenai tingkat umur tertentu untuk bekerja di sektor non pertanian. Pengelompokan umur responden dilakukan dalam upaya mempermudah proses pengolahan data. Umur responden yang telah beralih pekerjaan ini dibagi kedalam dua kelompok umur yaitu, kelomok umur muda ( $\leq 40$ tahun) adalah kelompok umur yang di bawah 40 tahun atau sama dengan 40 tahun dan kelompok umur tua (> 40 tahun) adalah responden yang berumur diatas 40 tahun. Gambaran mengenai kelompok umur responden dapat dilihat dalam Tabel 3. Berdasarkan Tabel 3 dapat dilihat umur responden yang telah beralih pekerjaan dari sektor pertanian 
ke sektor non pertanian kelompok umur $\leq 40$ tahun sama banyaknya dengan kelompok umur $>$ 40 tahun yaitu masing-masing berjumlah 15 responden $(50 \%)$. Dari hal ini dapat dilihat ternyata umur responden tidak berpengaruh terhadap peralihan tenaga kerja untuk bekerja disektor non pertanian dikarenakan responden yang telah beralih pekerjaan dari sektor pertanian ke sektor non pertanian adalah mereka yang sudah lama bekerja di sektor pertanian, karena untuk bekerja di sektor pertanian tidak tergantung dari umur para pekerja. Hal ini juga dikarenakan pekerjaan di sektor pertanian sudah menjadi pekerjaan secara turun temurun. Untuk bekerja di sektor non pertanian ternyata umur tenaga kerja mempengaruhi jenis pekerjaan yang akan dimasuki oleh tenaga kerja yang telah beralih pekerjaan. Jenis pekerjaan yang tergantung pada tingkat umur tenaga kerja seperti pegawai di pertokoan dan mart, dimana di jenis pekerjaan ini pihak perusahaan membatasi tingkat umur tenaga kerja yang ingin bekerja dan paling banyak tenaga kerja yang diterima adalah tenaga kerja berumur muda. Di sektor non pertanian juga banyak jenis-jenis pekerjaan yang tidak bergantung dari segi umur tenaga kerja, seperti yang diungkapkan oleh salah satu respoden ternyata untuk bekerja di sektor non pertanian khusunya di industri pala tidak tergantung pada umur para pekerja, yang terpentng masih dapat bekerja dengan baik semua orang dapat bekerja. Pekerjaan lain juga yang tidak menentukan batasan umur pekerja adalah buruh bangunan, karena untuk bekerja sebagai buruh bangunan tidak mementingkan umur tenaga kerja yang terpenting masih dapat bekerja dengan rajin juga masih kuat untuk bekerja di jenis pekerjaan ini.

\section{Jenis Kelamin}

Pekerjaan di sektor pertanian tidak hanya ditekuni oleh tenaga kerja laki-laki saja, namun tenaga kerja perempuan sangat diperlukan dalam kegiatan usaha tani. Pekerjaan di sektor pertanian laki-laki dan perempuan berbeda, tidak semua pekerjaan laki-laki disektor pertanian dapat ditangani oleh tenaga kerja perempuan. Pekerjaan perempuan hanya pekerjaan yang ringan seperti mencabut rumput di sawah, menyulam atau mengganti padi yang sudah mati, mengatur air dalam sawah, memupuk, menjemur hasil panen tidak seperti tenaga kerja laki-laki yang pekerjaannya adalah pekerjaan yang berat seperti membajak sawah dan mengangkat hasil panen. Jumlah tenaga kerja laki-laki di sektor pertanian cenderung lebih banyak di bandingkan dengan tenaga kerja perempuan karena peran laki-laki paling dominan untuk bekerja di sektor pertanian. Tabel 4 berikut ini memperlihatkan mengenai tenaga kerja dengan golongan jenis kelamin yang telah beralih pekerjaan dari sektor pertanian ke sektor non pertanian. Dari Tabel 4 dapat dilihat bahwa tenaga kerja laki-laki yang telah beralih pekerjaan ke sektor non pertanian berjumlah 23 orang $(76,7 \%)$ dibandingkan dengan tenaga kerja perempuan yang lebih sedikit jumlahnya yaitu 7 orang $(23,3 \%)$. Hal ini dikarenakan oleh dominasi laki-laki pada pekerjaan sebelumnya yaitu di sektor pertanian, maksudnya adalah mayoritas tenaga kerja yang berprofesi sebagai petani adalah laki-laki sehingga tenaga kerja yang telah beralih pekerjaan dari sektor pertanian ke sektor non pertanian sebagian besar adalah lakilaki.

Pergeseran tenaga kerja dari sektor pertanian ke sektor non pertanian yang didominasi oleh tenaga kerja laki-laki ternyata tidak mempengaruhi responden dalam memilih pekerjaan yang baru yaitu pekerjaan di sektor non pertanian hal ini dikarenakan jumlah responden laki-laki lebih banyak dari pada jumlah responden perempuan pada saat bekerja disektor pertanian.

\section{Pendidikan}

Pendidikan tenaga kerja di sektor pertanian umumnya beragam, mulai dari tenaga kerja yang tidak sekolah hingga yang berhasil lulus di SMA sederajat. Tenaga kerja yang beralih pekerjaan berdasarkan pendidikan dapat digolongkan menjadi 2 kelompok, yaitu pendidikan rendah ( $\leq$ tamat SMP sederajat) yaitu tenaga kerja yang tidak sekolah dan tenaga kerja yang berhasil menamatkan SMP sederajat dan kelompok yang kedua yaitu pendidikan tinggi (> tamat SMP) yaitu tenaga kerja yang menamatkan bangku SMA sederajat. Tenaga kerja yang telah beralih pekerjaan ini merupakan tenaga kerja yang tingkat pendidikannya kebanyakan tergolong rendah dikarenakan pekerjaan disektor pertanian tidak harus memiliki pendidikan yang tinggi dikarenakan pekerjaan di sektor pertanian merupakan pekerjaan yang sudah menjadi 
pekerjaan secara turun menurun dan sudah menjadi warisan dari keluarga. Penggolangan tingkat pendidikan ini berdasarkan pendidikan wajib belajar 9 tahun. Gambaran mengenai tingkatan pendidikan responden yang beralih pekerjaan dari sektor pertanian ke sektor non pertanian dapat dilihat dalam Tabel 5. Responden yang beralih pekerjaan dari sektor pertanian ke sektor non pertanian di Kecamatan Kalawat Kabupaten Minahasa Utara menurut tingkat pendidikan di bawah SMP sederajat berjumlah 20 orang $(66,7 \%)$ sedangkan diatas tamatan SMP sederajat berjumlah 10 orang $(33,3 \%)$. Hal ini dikarenakan tenaga kerja di sektor pertanian banyak yang tidak sekolah maupun hanya sampai SMP sederajat dikarenakan untuk bekerja di sektor pertanian tidak harus memiliki pendidikan yang tinggi dan juga pekerjaan di sektor pertanian yang sudah menjadi pekerjaan secara turun temurun dari keluarga. Tenaga kerja yang mempunyai tingkatan pendidikan yang tinggi tidak tertarik lagi untuk bekerja di sektor pertanian, hal ini disebabkan karena timbulnya pandangan yang rendah terhadap pekerjaan di sektor pertanian sehingga mereka tidak merasa pantas untuk bekerja di sektor pertanian.

Tabel 3. Umur Responden yang Beralih Pekerjaan dari Sektor Pertanian ke Non Sektor Pertanian di Kecamatan Kalawat 2016

\begin{tabular}{ccc}
\hline Kelompok Umur (Tahun) & Orang (responden) & $\%$ \\
\hline$\leq 40$ & 15 & 50 \\
$>40$ & 15 & 50 \\
\hline Jumlah & 30 & 100 \\
\hline
\end{tabular}

Sumber: diolah dari data primer, 2016

Tabel 4. Jenis Kelamin Responden yang Beralih Pekerjaan dari Sektor Pertanian ke Non Sektor Pertanian di Kecamatan Kalawat 2016

\begin{tabular}{ccc}
\hline Jenis Kelamin & Orang (responden) & $\%$ \\
\hline Laki-laki & 23 & 76,7 \\
Perempuan & 7 & 23,3 \\
\hline Jumlah & 30 & 100 \\
\hline
\end{tabular}

Sumber: diolah dari data primer, 2016

Tabel 5. Tingkat Pendidikan Responden yang Beralih Pekerjaan dari Sektor Pertanian ke Non Sektor Pertanian di Kecamatan Kalawat 2016

\begin{tabular}{ccc}
\hline Tingkat Pendidikan & Orang (responden) & $\%$ \\
\hline$\leq$ SMP & 20 & 66,7 \\
$>$ SMP & 10 & 33,3 \\
\hline Jumlah & 30 & 100 \\
\hline
\end{tabular}

Sumber: diolah dari data primer, 2016

Faktor Penyebab Pergeseran Tenaga Kerja Sektor Pertanian ke Sektor Non Pertanian

Faktor penyebab pergeseran tenaga kerja dari sektor pertanian ke sektor non pertanian terbagi dalam dua faktor yaitu, faktor pendorong dari sektor pertanian sehingga tenaga kerja sektor pertanian keluar meninggalkan pekerjaan di sektor pertanian dan faktor yang kedua adalah faktor penarik dari sektor non pertanian sehingga tenaga kerja memilih unruk bekerja di sektor non pertanian. 


\section{Faktor Pendorong dari Sektor Pertanian Sehingga Tenaga Kerja Meninggalkan Pekerjaan di Sektor Pertanian}

Berusaha tani merupakan pekerjaan yang sudah menjadi mata pencaharian masyarakat secara turun temurun, masyarakat telah menjadikan pertanian sebagai tempat untuk mendapatkan penghasilan demi kebutuhan hidup, baik untuk di konsumsi atau untuk dijual. Alihfungsi lahan pertanian menjadi lahan pemukiman penduduk membuat lahan pertanian digusur dan dijadikan tempat pemukiman penduduk mengingat pertumbuhan penduduk yang cepat. Masuknya sektor non pertanian di suatu wilayah pertanian jugan mengakibatkan alihfungsi lahan pertanian. Lahan yang dulunya dijadikan tempat untuk berusaha tani sekarang dijadikan tempat untuk kegiatan-kegiatan non pertanian, hal ini dirasakan pula oleh masyarakat petani Kecamatan Kalawat Kabupaten Minahasa Utara dimana Kecamatan Kalawat menjadi salah satu Kecamatan di Sulawesi Utara yang pertumbuhan sektor non pertaniannya tergolong cepat. Hal ini membuat tenaga kerja sektor pertanian tidak bisa lagi bekerja di sektor pertanian karena lahan untuk berusaha tani sudah tidak tersedia. Lahan yang dulunya merupakan tempat untuk berusaha tani dialihfungsikan menjadi lahan-lahan kegiatan non pertanian selain lahan kegiatan non pertanian, lahan pertanian dijadikan lahan pemukiman. Dorongan akan pemenuhan kebutuhan hidup, menyebabkan masyarakat mencari pekerjaan lain yang dapat mencukupi kebutuhan sehari-hari karena pekerjaan di sektor pertanian tidak lagi menjanjikan. Hal ini menjadi faktor pendorong dari sektor pertanian sehingga tenaga kerja meninggalkan pekerjaan di sektor pertanian. Hal ini dapat di lihat dari Tabel 6 yaitu alasan responden meninggalkan pekerjaan di sektor pertanian. Dari Tabel 6 dapat dilihat alasanalasan responden meninggalkan pekerjaan di sektor pertanian serta banyaknya responden yang menjawab alasan tersebut. Alasan-alasan tersebut yang mendasari terjadinya pergeseran tenaga kerja sektor pertanian ker sektor pertanian di Kecamatan Kalawat Kabupaten Minahasa Utara. Selain dari Tabel 6 alasanalasan responden meninggalkan pekerjaan di sektor pertanian di Kecamatan Kalawat hal ini dapat dilihat pula dalam Gambar 1.

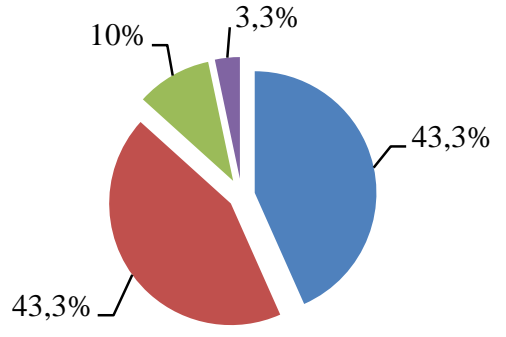

- Upah di sektor pertanian tidak menentu/rendah

- Lahan semakin sempit/sudah tidak ada

- Pandangan rendah terhadap pekerjaan di pertanian

- Jenuh/bosan bekerja di pertanian

Gambar 1. Alasan Responden Meninggalkan Pekerjaan di Sektor Pertanian di Kecamatan Kalawat Tahun 2016

Sumber: diolah dari data primer, 2016

Dari Tabel 6 dan Gambar 1 dapat dilihat berbagai alasan yang diungkapkan oleh responden seperti upah disektor pertanian yang tidak menentu/rendah $(43,3 \%)$ sehingga tidak dapat memenuhi kebutuhan mereka. Dimana upah disektor pertanian didapat hanya pada setiap panen dan dipengaruhi oleh iklim cuaca membuat pendapatan seringkali tidak tetap dan secara riil menurun dan rendah. Alasan ini membuat tenaga kerja terdorong untuk keluar dari sektor pertanian dikarenakan kebutuhan sehari-hari mereka tidak bisa terpenuhi jika harus menunggu hasil panen. Para pekerja yang beralih pekerjaan ini lebih memilih pekerjaan yang mengasilkan pendapatan yang cepat untuk mencukupi kebutuhan seharihari dari pada harus menunggu hasil panen yang belum tentu besar.

Upah di sektor pertanian yang tidak tetap dan secara riil menurun membuat tenaga kerja sektor pertanian keluar dari sektor pertanian dan memilih untuk bekerja di sektor non pertanian, seperti pekerjaan sebagai buruhbangunan yang upahnya tetap setiap minggu membuat tenaga kerja lebih memilih untuk bekerja sebagai buruh bangunan walaupun upah sebagai buruh bangunan tidak sebesar upah di sektor pertanian yang diterima pada saat panen. Hal dikarenakan upah yang tetap setiap minggunya lebih baik dari pada upah yang besar tetapi harus menunggu jangka waktu yang lama sedangkan mereka mempunyai kebutuhan sehari-hari yang tidak bisa menunggu saat panen tersebut. 
Lahan yang semakin menyempit dan ketersediaan lahan yang sudah tidak ada $(43,3 \%)$ karena dampak dari pembangunan khususnya di Kecamatan Kalawat tidak sedikit lahan pertanian yang dialihfungsikan untuk dijadikan tempat pemukiman juga pembangunan jalan tol. Hal ini membuat tenaga kerja terdorong keluar mencari pekerjaan di sektor non pertanian dikarenakan lahan mereka untuk berusaha tani telah dialihfungsikan untuk dijadikan lahan pemukiman juga jalan tol membuat para tenaga kerja tidak bisa lagi bekerja sebagai petani. Lahan yang semakin berkurang membuat hasil panenpun menjadi sedikit karena lahan untuk ditanami menjadi kecil dan mempengaruhi hasil panen yang juga dipengaruhi oleh iklim cuaca yang membuat pendapatan menjadi lebih sedikit membuat petani keluar mencari pekerjaan lain. Adapun tenaga kerja yang lebih muda dan berpendidikan tinggi merasa pekerjaan di pertanian adalah pekerjaan yang rendah (10\%) dibandingkan dengan pekerjaan di sektor non pertanian dikarenakan pekerjaan di sektor pertanian dianggap sudah tidak menarik lagi sehingga membuat responden merasa jenuh dan bosan untuk bekerja di sektor pertanian $(3,3 \%)$ dan membuat responden dari sektor pertanian dan ingin mencari pekerjaan lain dan ingin mencari suasana lain di luar sektor pertanian.

Alasan-alasan yang dikemukakan responden dan telah dijelaskan merupakan faktor pendorong bagi tenaga kerja sektor pertanian untuk keluar dari sektor pertanian dan beralih pekerjaan di sektor lain.

Faktor Penarik dari Sektor Non Pertanian Sehingga Tenaga Kerja Memilih untuk Bekerja di Sektor Non Pertanian

Selain faktor pendorong dari sektor pertanian sehingga tenaga kerja meninggalkan sektor pertanian ada juga faktor penarik dari sektor non pertanian sehingga tenaga kerja memilih untuk bekerja di sektor non pertanian. Faktor penarik inilah yang membuat tenaga kerja sektor pertanian meninggalkan sektor pertanian dan memilih untuk bekerja di sektor non pertanian. Alasan-alasan yang diberikan oleh responden berikut ini merupakan faktor penarik dari sektor non pertanian yang membuat responden meninggalkan pekerjaan di sektor pertanian, serta banyaknya jawaban responden dan presentasenya dapat dilihat dalam Tabel 7 dan Gambar 2.

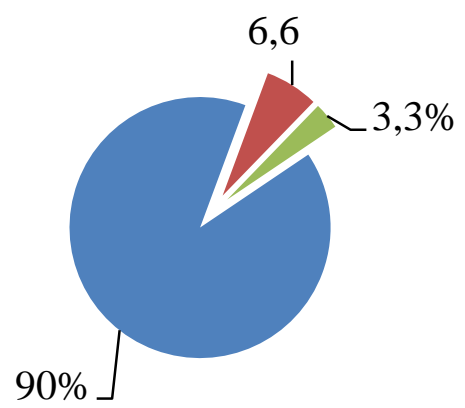

- Peluang atau kesempatan kerja terbuka

- Pendapatan tetap dan cepat juga lebih menjanjikan

Kondisi pekerjaan yang lebih menjanjikan

Gambar 2. Alasan Responden Mememilih Untuk Bekerja di Sektor Non Pertanian di Kecamatan Kalawat Tahun 2016

Sumber: diolah dari data primer, 2016

Terbukanya peluang atau kesempatan untuk bekerja di sektor non pertanian (90\%) sebagai akibat dari banyaknya perumahan serta gedung-gedung yang akan dibangun memerlukan tenaga kerja yang banyak, juga dalam pembangunan jalan-jalan pedesaan membutuhkan tenaga kerja yang membuat para tenaga kerja di sektor pertanian menjadi tertarik untuk bekerja di sektor non pertanian. Penggusuran lahan-lahan pertanian untuk dijadikan lahan pemukiman dan pekuburan serta dijadikan lahan pembangunan jalan tol ini mempunyai dampak terhadap tenaga kerja yang beralih pekerjaan ini, banyak yang memilih untuk bekerja sebagai tukang atau buruh karena permintaan tenaga kerja di jenis pekerjaan ini tergolong banyak yang membuat tenaga kerja yang beralih pekerjaan terserap masuk di jenis pekerjaan ini. Peluang dan kesempatan untuk bekerja di sektor non pertanian bukan hanya di bidang tukang atau buruh bangunan, tetapi juga terbuka di bidang lain seperti tukang ojek karena untuk bekerja dijenis pekerjaan ini tidak memerlukan syarat-syarat khusus yang terpenting mempunyai keahlian mengemudi serta ketersediaan alat transportasi yaitu sepeda motor, tetapi bagi yang tidak punya sepeda motor tapi ingin bekerja sebagai tukang ojek sudah ada perusahaan jasa tukang ojek yang menyediakan alat transportasi tetapi dengan syarat dan ketentuan dari pihak perusahaan.

Selain kesempatan yang terbuka untuk bekerja di sektor non pertanian, pendapatan tetap serta lebih menjanjikan $(6,6 \%)$ membuat responden memilih untuk bekerja di sektor non 
pertanian. Pendapatan yang setiap minggunya diterima seperti dalam pekerjaan sebagai buruh bangunan sekalipun tidak lebih besar pendapatan di sektor pertanian pada saat panen membuat tenaga kerja lebih memilih untuk bekerja di sektor non pertanian karena pendapatan yang tetap setiap minggunya masih dianggap lebih baik dari pada pendapatan yang besar tetapi memiliki jangka waktu yang tergolong lambat dan hanya pada setiap waktu panen. Hal ini membuat tenaga kerja memilih untuk bekerja di sektor non pertanian karena kebutuhan hidup sehari-hari mereka tidak bisa menunngu pada saat panen. Seperti pekerjaan dibidang tukang atau buruh pendapatan yang setiap minggu didapat dianggap lebih baik dari pada untuk menunggu hasil panen yang tidak menentu dan cenderung rill menurun rendah. Responden juga memandang kondisi pekerjaan di sektor non pertanian lebih menjanjikan dan nyaman $(3,3 \%)$ dari pada bekerja di sektor pertanian karena bekerja di sektor non pertanian memiliki upah yang tetap setiap minggunya. Alasan lain juga yang mempengaruhi responden untuk bekerja di sektor non pertanian yaitu karena responden memiliki keahlian khusus seperti menjadi tukang gunting rambut dan mengemudi, baik mengemudi sepeda motor (tukang ojek) maupun mobil (supir mikrolet dan supir di bagian gudang industri), dari keahlihan khusus inilah responden bisa bekerja di sektor non pertanian. Tetapi ada juga pekerjaan yang tidak terlalu membutuhkan keahlian khusus dan syarat untuk bekerja di sektor non pertanian, khusunya dipekerjaan buruh industri pala di Kecamatan Kalawat. Seperti pengakuan salah satu responden yang bekerja sebagai buruh indutri pala mengatakan bahwa untuk bekerja di industri pala tidak harus memiliki syarat dan keahlian khusus untuk bekerja, seperti pendidikan yang tinggi, yang terpenting masih dapat bekerja dengan cermat dan rajin ternyata pihak perusahaan dapat menerima msayarakat untuk bekerja. Ketersediaan alat sarana dan prasarana juga menjadi alasan responden untuk bekerja di sektor non pertanian, seperti pekerjaan sebagai tukang ojek dan tukang gunting rambut. Hal ini dikarenakan responden memiliki alat gunting dan alat trasportasi yaitu sepeda motor membuat responden tertarik dan memilih untuk bekerja di sektor non pertanian.. Faktor-faktor penarik inilah yang kemudian membuat tenaga kerja sektor pertanian beralih pekerjaan ke sektor non pertanian.

\section{Pekerjaan Responden Setelah Beralih Pekerjaan ke Sektor Non Pertanian}

Jenis pekerjaan responden setelah beralih pekerjaan dari sektor pertanian ke sektor non pertanian sangat beragam mulai dari bekerja sebagai tukang ojek $(6,7 \%)$ juga bekerja sebagai buruh bangunan $(36,7 \%)$. Hal ini dikarenakan para pekerja yang beralih pekerjaan setelah keluar dari sektor pertanian, mancari pekerjaan di sektor non pertanian dikarenakan mereka tidak bisa lagi bekerja sebagai petani. Hal ini disebabkan oleh alihfungsi lahan menjadi lahan kegiatan sektor non pertanian. Tabel 8 dibawah ini dapat dilihat jenis-jenis pekerjaan responden yang telah beralih pekerjaan. Dari Tabel 8 dapat dilihat pekerjaanpekerjaan responden setelah beralih pekerjaan. Tenaga kerja yang telah beralih pekerjaan ini terserap di berbagai jenis pekerjaan sektor non pertanian dengan berbagai alasan masing-masing responden. Tenaga kerja yang telah beralih pekerjaan ini adalah petani penggarap. Petani penggarap adalah mereka yang meminjam atau menyewa lahan dari masyarakat asli Kecamatan Kalawat Kabupaten Minahasa Utara dikarenakan mereka adalah masyarakat pendatang di Kecamatan Kalawat dan mereka tidak mempunyai lahan pertanian dan setelah lahan pertanian yang mereka pinjam dan sewa telah dijual dan dialihfungsikan mereka tidak bisa bekerja lagi sebagai petani.

Jenis-jenis pekerjaan responden setelah beralih pekerjaan juga dapat dilihat dari Gambar 3 .

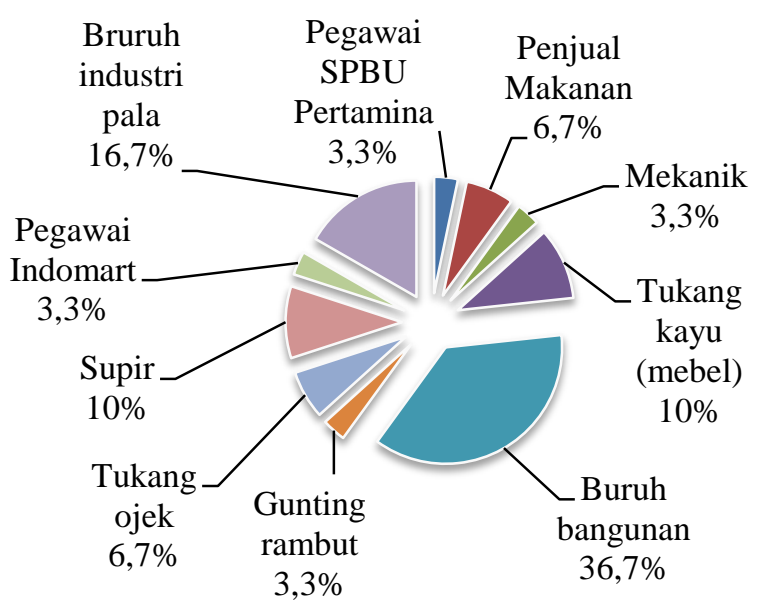

Gambar 3. Pekerjaan Responden yang Beralih Pekerjaan dari Sektor Pertanian ke Non Sektor Pertanian di Kecamatan Kalawat 2016

Sumber: diolah dari data primer, 2016 
Dapat dilihat dari Tabel 8 dan Gambar 3, profesi yang banyak digeluti oleh responden yang telah beralih pekerjaan adalah bekerja sebagai tukang atau buruh, baik buruh banguna yaitu sebanyak 11 orang $(36,7 \%)$. Para pekerja yang terserap di pekerjaan ini juga dikarenakan adanya peluang dan kesempatan untuk bekerja, hal ini dikarenakan di Kecamatan Kalawat banyak pembangunan rumah pemukiman dan gedung-gedung non pertanian serta pembangunan infrastruktur Kecamatan Kalawat seperti jalan desa dan pembangunan jalan tol yang membutuhkan tenaga kerja yang banyak sehingga tenaga kerja pertanian beralih pekerjaan di sektor non pertanian sebagai buruh bangunan. Bukan hanya peluang dan kesempatan kerja yang terbuka di sektor non pertanian yang mebuat tenaga kerja beralih pekerjaan ke sektor non pertanian sebagai buruh bangunan, upah tenaga sebagai buruh bangunan juga menjadi alasan tenaga kerja untuk beralih pekerjaan sebagai buruh bangunan karena upah sebagai buruh bangunan yang tetap setiap minggunya dan pendapatan yang diterima tenaga kerja setiap minggunya. Berbeda dengan upah di sektor pertanian yang tidak menentu dan hanya didapat pada saat hasil panen, walaupun upah sebagai buruh bangunan setiap minggunya tidak sebesar upah di sektor pertanian pada saat panen membuat tenaga kerja lebih memilih untuk bekerja sebagai buruh bangunan karena upah yang tetap setiap minggunya. Salah satu responden juga mengatakan bahwa pendapatan saat bekerja sebagai tukang lebih baik dari pada bekerja sebagai petani dikarenakan pendapatan yang cepat juga tetap yang didapat pada setiap minggu walaupun tidak sebesar pendapatan sebagai petani pada saat panen tetapi masih lebih baik dari pada harus menunggu saat panen yang terpenting dapat memenuhi kebutuhan sehari-hari.

Profesi lain tenaga kerja yang beralih pekerjaan adalah tukang kayu (mebel) dan supir dengan jumlah responden masing-masing sebanyak 3 orang $(10 \%)$. Untuk bekerja sebagai supir haruslah memiliki keahlian khusus yaitu mengemudi. Profesi lain yang harus memiliki keahlian khusus adalah tukang gunting rambut $(3,3 \%)$. Ketersediaan alat juga haruslah tersedia untuk bekerja di jenis pekerjaan ini, pekerjaan lain yang juga harus memiliki alat adalah tukang ojek $(6,7 \%)$, jika tidak memiliki sepeda motor dan juga tidak memiliki keahlian dalam mengemudi sepeda motor maka tidak bisa bekerja sebagai tukang ojek. Jenis pekerjaan lain yang dimasuki responden yang telah beralih pekerjaan adalah mekanik $(3,3 \%)$ jenis pekerjaan ini haruslah tenaga kerja laki-laki karena pekerjaan ini adalah pekerjaan yang berat dan hanya bisa dilakukan oleh laki-laki. Profesi lain juga yang menjadi pilihan responden adalah bekerja sebagai pegawai SPBU Pertamina $(3,3 \%)$ dan Juga Pegawai Indomart $(3,3 \%)$. Untuk tenaga kerja perempuan yang telah beralih pekerjaan memasuki jenis pekerjaan seperti buruh industri $(16,7 \%)$ dengan jumlah responden sebanyak 5 orang. Tenaga kerja perempuan juga ada yang bekerja sebagai penjual makanan $(6,7 \%)$. Profesi-profesi yang digeluti para pekerja yang telah beralih pekerjaan dari sektor pertanian ke sektor non pertanian tidak lepas dari faktor pendorong dari sektor pertanian dikarenakan ketersediaan lahan untuk berusaha tani yang membuat para pekerja sektor pertanian terpaksa mencari pekerjaan lain di luar sektor pertanian. Seperti salah satu pengakuan responden yang telah beralih pekerjaan mengatakan bahwa adanya pembangunan jalan tol juga lahan pekuburan, membuat banyak lahan pertanian yang telah digusur unutuk dijadikan jalan dan lahan pekuburan, ini membuat masyarakat tidak bisa lagi bekerja sebagai petani karena sudah tidak memiliki lahan untuk bertani. Hal ini ternyata membuat tenaga kerja pertanian tidak bisa lagi bekerja sebagai petani. Pergeseran tenaga kerja ini juga dikarenakan oleh masuknya sektor non pertanian di suatu wilayah pertanian. Munculnya sektor non pertanian yang menjadi sektor economically promosing sebagai sektor yang dapat menampung tenaga kerja yang banyak dan juga diperkuat dengan faktor penarik dari sektor non pertanian itu sendiri yaitu adanya peluang dan kesempatan untuk bekerja di sektor non pertanian membuat tenaga kerja tertarik untuk terjun dalam sektor non pertanian.

Tenaga kerja yang telah beralih pekerjaan ini adalah petani penggarap. Petani penggarap adalah mereka yang meminjam atau menyewa lahan dari masyarakat asli Kecamatan Kalawat Kabupaten Minahasa Utara dikarenakan mereka adalah masyarakat pendatang di Kecamatan Kalawat dan mereka tidak mempunyai lahan pertanian dan setelah lahan pertanian yang mereka pinjam dan sewa telah dijual dan dialihfungsikan mereka tidak bisa bekerja lagi sebagai petani. 
Tabel 6. Alasan Responden Meninggalkan Pekerjaan di Sektor Pertanian di Kecamatan Kalawat Tahun 2016

\begin{tabular}{lcc}
\hline \multicolumn{1}{c}{ Alasan } & $\begin{array}{c}\text { Jawaban } \\
\text { (responden) }\end{array}$ & $\%$ \\
\hline Upah di sektor pertanian tidak menentu/rendah & 13 & 43,3 \\
Lahan semakin sempit/lahan sudah tidak ada & 13 & 43,3 \\
Pandangan rendah terhadap pekerjaan di pertanian & 3 & 10 \\
Jenuh/bosan bekerja di pertanian & 1 & 3,3 \\
\hline JUMLAH & 30 & 100 \\
\hline
\end{tabular}

Sumber: diolah dari data primer, 2016

Tabel 7. Alasan Responden Memilih Untuk Bekerja di Sektor Non Pertanian di Kecamatan Kalawat Tahun 2016

\begin{tabular}{lcc}
\hline \multicolumn{1}{c}{ Alasan } & $\begin{array}{c}\text { Jawaban } \\
\text { (responden) }\end{array}$ & $\%$ \\
\hline Peluang atau kesempatan kerja terbuka & 27 & 90 \\
Pendapatan tetap juga lebih menjanjikan & 2 & 6,6 \\
Kondisi pekerjaan yang menjanjikan dan nyaman & 1 & 3,3 \\
\hline \multicolumn{1}{c}{ JUMLAH } & 30 & 100 \\
\hline
\end{tabular}

Sumber: diolah dari data primer, 2016

Tabel 8. Pekerjaan Responden yang Beralih Pekerjaan dari Sektor Pertanian ke Non Sektor Pertanian di Kecamatan Kalawat 2016

\begin{tabular}{lcc}
\hline \multicolumn{1}{c}{ Pekerjaan } & Orang (responden) & $\%$ \\
\hline Pegawai SPBU Pertamina & 1 & 3,3 \\
Penjual Makanan & 2 & 6,7 \\
Mekanik (ketok magik) & 1 & 3,3 \\
Tukang Kayu (mebel) & 3 & 10 \\
Tukang (Buruh bangunan, pembangunan jalan) & 11 & 36,7 \\
Gunting rambut & 1 & 3,3 \\
Tukang ojek & 2 & 6,7 \\
Supir mikro dan gudang & 3 & 10 \\
Pegawai indomart & 1 & 3,3 \\
Buruh industri pala & 5 & 16,7 \\
\hline
\end{tabular}

Sumber: diolah dari data primer, 2016 


\section{KESIMPULAN DAN SARAN}

\section{Kesimpulan}

Penyebab bergesernya tenaga kerja sektor pertanian ke sektor non pertanian dapat dibagi dalam dua kategori yakni, faktor pendorong dari sektor pertanian dan faktor penarik dari sektor non pertanian. Faktor pendorong dari sektor pertanian yang membuat tenaga kerja meninggalkan sektor pertanian disebabkan oleh upah di sektor pertanian yang tidak menentu dan cenderung rendah serta ketersediaan lahan pertanian yang semakin menyempit. Faktor penarik dari sektor non pertanian yang membuat tenaga kerja pertanian keluar dari sektor pertanian dan memilih pekerjaan di sektor non pertanian paling besar disebabkan oleh, peluang dan kesempatan kerja di sektor non pertanian yang terbuka.

\section{Saran}

1. Perlu adanya aturan yang ketat untuk alihfungsi lahan pertanian menjadi lahan non pertanian, sehingga luas lahan pertanian tidak semakin berkurang.

2. Upah di sektor pertanian perlu juga diperhatikan agar bisa bersaing dengan upah di sektor non pertanian.

\section{DAFTAR PUSTAKA}

Anwar, Yunizar, Nidar, 2007. Identifikasi Sektor Industri dan Peranannya dalam Peningkatan Pendapatan Asli Daerah Kabupaten Garut. Jurnal Universitas Padjajaran.

Badan Pusat Statistik, 2016. Minahasa Utara Dalam Angka 2014. Katalog BPS Minahasa Utara.

Dalam Angka 2015. Katalog BPS Minahasa Utara.

Dalam Angka 2016. Katalog BPS Minahasa Utara.
Dinaryanti N, 2014. Faktor-Faktor Yang Mempengaruhi Alih Fungsi Lahan Pertanian Di Daerah Sepanjang Irigasi Bendung Colo Kabupaten Sukorajo. Skripsi Universitas Diponegoro.

Mulyadi S, 2014. Ekonomi Sumber Daya Manusia Dalam Perspektif Pembangunan. Penerbit Rajagrafindo Persada.

Ndawa, Johanis Jonick J, 2014. Dampak Alih Penggunaan Lahan Pertanian Ke Non Pertanian Terhadap Kesempatan Kerja Dan Pendapatan Rumah Tangga Petani Di Kota Batu (Studi Kasus Desa Oro-Oro OmboBatu). Jurnal Universitas Brawijaya Malang.

Noragawati, Lylyn, 2002. Faktor Penyebab Pergeseran Tenaga Kerja Dari Sektor pertanian Ke Sektor Non Pertanian Pada Masyarakat Desa Telukpinang Kecamatan Ciawi Kabupaten Bogor. Skripsi Institut Pertanian Bogor.

Putra, Aditya Perdana, 2013. Analisis Penyerapan Tenaga Kerja Sektor Industri Mabel di Kabupaten Pinrang. Jurnal Universitas Hasanudin.

Ratnaningsih, Eka Suci, 2013. Pengaruh Pertumbuhan Sektor Industri Terhadap Penyerapan Tenaga Kerja Di Kota Surabaya. Jurnal Universitas Negeri Surabaya.

Raya, Bihrajihant Alia dan Subejo, 2010. Jurnal Ilmu-Ilmu Pertanian: Opini Masyarakat Terhadapa Citra Komoditas Pangan Lokal ( Studi Kasus Opini Pemuda Pedesaan Yogyakarta dan Mahasiswa Fakultas Pertanian UGM). Jurnal Sekolah Tinggi Penyluhan Pertanian Magelang.

Saputri, Oktaviana Dwi, 2010. Analisis Penyerapan Tenaga Kerja Di Kota Salatiga. Jurnal.

Setyoko, Bayu, 2013. Faktor-Faktor Yang Mempengaruhi Keputusan Petani Mengkonversi Lahan Pertanian Menjadi Lahan Non Pertanian: Petani Desa Kopeng, Kecamatan Getasan, Kabupaten Semarang. Skripsi Universitas Diponorogo. 
Sugiyono, 2014. Metode Penelitian Kuantitatif Kualitatif Dan R\&D. Penerbit Alfabeta.

Sumanto, Agus, 2009. Identifikasi Faktor-Faktor Sosial-Ekonomi Migrasi Tenaga Kerja: Kasus Ibu Rumah Tangga yang Bekerja dari Sektor Pertanian ke Sektor Non Pertanian. Jurnal Universitas Negeri Malang.
Suwartapradja, Opan S, 2008. Kolektivitas Tenaga Kerja Dalam Pertanian: Studi Tentang Implikasi Curahanh Tenaga Kerja Terhadap Pendapatan Petani di Kabupaten Sumedang, Jawa Barat. Jurnal UNPAD.

Tambunan, Donald, 1999. Pergeseran Tenaga Kerja Muda Dari Sektor Pertanian Ke Luar Pertanian Dan Fenomena Migrasi Akibat Pembangunan Industri Di Pedesaan: Kasus Desa Bitung Sari, Kecamatan Ciawi, Kabupaten Bogor. Skripsi Institut Pertanian Bogor. 